\title{
Prevalence and predictors of burnout and psychological distress among physicians in specialty training in palliative care: A Japanese nationwide study
}

\author{
Matsumoto $\mathrm{Y}^{1)}$, Uehara $\mathrm{Y}^{1) 2}$, Mizushima $\mathrm{A}^{2)}$, Nozato $\mathrm{J}^{3)}$, Miyamoto $\mathrm{S}^{4)}$, Mori $\mathrm{M}^{5)}$, Nishi $\mathrm{T}^{6)}$, \\ Kizawa $\mathrm{Y}^{7)}$, Morita $\left.\mathrm{T}^{8}\right)$
}

1) National Cancer Center Hospital East, Department of Palliative medicine, Kashiwa, Japan

2) Juntendo University School of Medicine, Department of Palliative Medicine, Tokyo, Japan

3) Tokyo Medical and Dental University, Department of Cancer Center, Tokyo, Japan

4) Japanese Red Cross Medical Center, Department of Medical Oncology, Tokyo, Japan

5) Seirei Mikatahara General Hospital, Palliative care team, Hamamatsu, Japan

6) Kawasaki Municipal Ida Hospital, Kawasaki Comprehensive Care Center, Kawasaki, Japan

7) Kobe University Graduate School of Medicine, Department of Palliative Medicine, Kobe, Japan

8) Seirei Mikatahara General Hospital, Palliative and Supportive Care Division, Hamamatsu, Japan.

\section{Aim}

To clarify the prevalence of burnout and psychological distress among physicians in specialty training in palliative care, and to explore predictors of burnout and psychological distress.

\section{Background}

Previous researches have reported high rate of burnout and psychological distress in health care providers. Because palliative care physicians are placed under a stressful environment where they routinely face patients with significant suffering, we should pay attention to their burnout and psychological distress, especially among younger physicians who may have burnout more easily than older physicians.

\section{Methods}

- Using a double-envelope method, we sent participation requests with questionnaires for distribution to eligible physicians in specialty training in palliative care, working in the institutes which were certified for palliative care training by the Japanese Society for Palliative Medicine (total number of institutions: 735 in October 2013).

- Participants were asked to complete the Maslach Burnout Inventory (MBI), K6, participants' characteristics and unmet learning needs. High levels of burnout and psychological distress were identified using cut-off scores of the MBI(emotional exhaustion [EE, $\geqq 27$, depersonalization $[\mathrm{DP}, \geqq 10]$ and personal accomplishment $[\mathrm{PA}, \leqq 33])$ and $\mathrm{K} 6(\geqq 5)$, respectively.

\section{Results}

- In total, 253 of 735 institutions (34\%) responded; of 284 physicians, $253(89 \%)$ responded and 229 were eligible. The characteristics of the participants are summarized in Table 1.

- Overall, $69.4 \%$ of the respondents had burnout: $19.2 \%$ with high EE; 7.4\% with high DP; and 65.9\% with low PA (Table 2).

- Thirty percent had psychological distress (Table 2).

- In multivariate analysis, high EE, high DP and low PA were significantly associated with psychological distress (Odds Ratio [95\% confidence intervals] of 9.3 [4.4-19.5], 6.3 [2.1-18.8] and $4.0[1.8-8.6] ; \mathrm{P}<0.001, \mathrm{P}=0.001$ and $\mathrm{P}=0.001$, respectively).

Table2. Prevalence of burnout and psychological distress

\begin{tabular}{l|c}
\hline $\begin{array}{l}\text { EE } \\
\geqq 27\end{array}$ & No. of respondents $(\%)$ \\
\hline DP & $44(19.2)$ \\
$\quad \geqq 10$ & $17(7.4)$ \\
\hline AA & $151(65.9)$ \\
Any of EE, DP and PA is more than cut off scores & $159(69.4)$ \\
K6 & \\
$\geqq 5$ & $69(30.1)$ \\
$\geqq 9$ & $39(14.4)$
\end{tabular}

EF; emotional exhaustion, DP; depersonalization, PA; personal accomplishment

\section{Acknowledgements}

We are grateful to Drs. Toru Okuyama and Asao Ogawa for their support in the development of the questionnaire, and the members of Research and Education Group (P-CREG) for helpful discussions.

This work was supported by the Sasakawa Memorial Health Foundation for its generous grant support (2013-a009).

\section{Disclosure Potential Conflict of Interest}

I have no potential conflict of interest to report.
Table 1. Characteristics of the Study Participants ( $=229)$

\begin{tabular}{|c|c|}
\hline & No. of respondents \\
\hline Mean age (standard deviation) & $35(4.8)$ \\
\hline $\begin{array}{l}\text { Sex a }(\%) \\
\text { Male } \\
\text { Female }\end{array}$ & $\begin{array}{l}136(59) \\
92(40)\end{array}$ \\
\hline Mean years of clinical experience (standard deviation) & $8.9(3.7)$ \\
\hline $\begin{array}{l}\text { Institutions a }(\%) \\
\text { Designated cancer hospitals } \\
\text { University hospitals } \\
\text { Other hospitals }\end{array}$ & $\begin{array}{l}100(44) \\
72(31) \\
56(25)\end{array}$ \\
\hline $\begin{array}{l}\text { Working at institutions certified for palliative medicine } \\
\text { training by the Japanese Society for Palliative Medicine a (\%) } \\
\text { Yes } \\
\text { No }\end{array}$ & $\begin{array}{c}176(77) \\
39(17)\end{array}$ \\
\hline $\begin{array}{l}\text { Duration working at current institution a }(\%) \\
<1 \text { year } \\
\geqq 1 \text { year }\end{array}$ & $\begin{array}{l}69(30) \\
159(69)\end{array}$ \\
\hline $\begin{array}{l}\text { Main workplace over past month }{ }^{\mathrm{b}}(\%) \\
\text { Palliative care team } \\
\text { Palliative care units } \\
\text { Home }\end{array}$ & $\begin{array}{l}91(40) \\
66(29) \\
13(5.7)\end{array}$ \\
\hline $\begin{array}{l}\text { Specialties }(\%) \\
\text { Internal medicine } \\
\text { Anesthesiology } \\
\text { Surgery } \\
\text { Others }\end{array}$ & $\begin{array}{l}107(47) \\
45(20) \\
27(12) \\
50(22)\end{array}$ \\
\hline $\begin{array}{l}\text { Median number of palliative care physicians at same } \\
\text { institution (range) }\end{array}$ & $3(0-15)$ \\
\hline $\begin{array}{l}\text { Median number of cancer patients who died under the care of } \\
\text { a participant in past year (range) }\end{array}$ & $40(0-500)$ \\
\hline
\end{tabular}

\section{References}

- Asai M, et al. Psychooncology 2007.

- Kamal AH, et al. J Pain Symptom Manage 2016.

- Parola V, et al. JBI Database System Rev Implement Rep. 2017

- Lupu D. J Pain Symptom Manage 2010. 